\title{
Beyond the indigenous/Phoenician binomial: spheres of interaction and scales of integration in the Early Iron Age of southern Portugal (8th-5th centuries BCE)
}

\author{
Para lá do binómio indígena/fenício: esferas de interação e escalas de \\ integração na I idade do ferro do Sul de Portugal (séculos VIII - V a.C.)
}

GOMES, F. B. Beyond the indigenous/Phoenician binomial: spheres of interaction and scales of integration in the Early Iron Age of southern Portugal (8th-5th centuries BCE). R. Museu Arq. Etn., 33: 15-27, 2019.

\begin{abstract}
The arrival of the first Phoenician merchants and colonists in the far western portions of the Iberian Peninsula destabilised the delicate balance of the regional Late Bronze Age networks, unleashing a wide-ranging process that would completely change the socio-political landscape of southern Portugal. However, the growing volume of data shows that, far from being a linear and straightforward process, the ensuing restructuration was complex and dynamic. Following this reasoning, we argue that "traditional" models based on normative views of culture can no longer explain the diversity of the archaeological record, requiring new and more nuanced approaches. We particularly suggest that such diversity reflects specific representational discourses that combine "traditional" and innovative elements, often exogenous, according to variable identity discourses, historically situated and socially negotiated, destined to be deployed on multiple levels - from the microregional context of intra- and intergroup interactions, to the transregional, Mediterranean level.
\end{abstract}

Keywords: Late Bronze Age; Early Iron Age; burial practices; representation practices; identity discourses.

Some background: the Phoenician colonization and the beginning of the Early Iron Age in southern Portugal

$\mathrm{R}$ ecent studies on migration and Colonialism in the ancient world especially in the ancient Mediterranean -

*Post-Doctoral Fellow, Universidade de Lisboa. <franciscojbgomes@gmail.com> have undergone a significant theoretical and methodological renewal, fuelled primarily by the growing influence of concepts and approaches borrowed from postcolonial studies (Lyons \& Papadopoulos 2002; Gosden 2004; Dietler 2010; van Dommelen 2011). The prior emphasis on colonizing groups and their agendas and strategies has slowly shifted, as more and more research projects, inspired by on-going debates in other fields, 
focus on the local responses to colonial processes (Hodos 2006), the creative processes of negotiation and appropriation between newcomers and local groups, and the processes by which new, complex, and entangled cultural identities were forged in intercultural contexts (van Dommelen 2005; Vives-Ferrándiz Sánchez 2008; Dietler 2010).

Contributing to this trend, this study aims to discuss some limitations posed by the traditional thinking regarding relations between Phoenician colonists and indigenous people of southwestern Iberia. To do so, we prompt some reflections on the impact of the oriental presence in the cultural processes and representational discourses of Early Iron Age communities in southern Portugal. But before entering these reflections, we must outline the general historical background of the political, social, and cultural processes that this text will discuss.

An overview of these processes must begin in the final stages of the Bronze Age. It seems that, during this period, the political landscape in southern Portugal was quite fragmentary, characterized by interconnected but autonomous socio-political units structuring specific, small-scale territories (Mataloto 2012, 2013; Soares 2013). These, in turn, were articulated in a complex socio-political network whose functioning depended on an unstable and competitive balance between communities and, especially, local elite groups (Gomes, F.B. 2015a).

The delicate balance of this socio-political network was destabilised by the arrival of the first Phoenician merchants and colonists in the far western portions of the Iberian Peninsula. The presence and influence of exogenous, oriental groups in the Portuguese territory was well documented, at least since the 8th century BCE., ${ }^{1}$ in the Lower Tagus valley (Arruda 2005) and, surprisingly, in the inner region of Alentejo (Berrocal-Rangel \& Silva 2010).

1 All dates are given in "traditional" chronology. The earlier phases of the Iron Age of southwestern Iberian seems to attribute a substantial discrepancy between the traditional, typology-based chronologies and the absolute, radiocarbon-based chronologies. For a discussion of chronological issues in the southern Portuguese Early Iron Age see Soares \& Arruda (2017).
The differential access to the Phoenician colonial and commercial interface - which acted as an active bond between the regional, social, political, and economic network and the transregional networks, on a much larger scale apparently shook off that unstable balance, benefiting the coastal regions in detriment of the inner regions. The socio-political structures of the Late Bronze Age collapsed in a rather short period in the inner regions (Mataloto 2004a; Berrocal-Rangel \& Silva 2010; Gomes F.B. 2015a) - a process categorized by social unrest and possible violent events, as attested in the important site of Castro dos Ratinhos (Berrocal-Rangel \& Silva 2010).

Conversely, the coastal areas responded quite differently to this new geopolitical situation. The Phoenician presence seems to have spread during the first half of the 7th century, culminating with the emergence of a fully structured network of "orientalising" settlements (Arruda 2000) (FIGURE 1) in both areas, with roots in the Late Bronze Age, where material record shows that oriental-like traits were largely adopted, such as in Castro Marim (Arruda 2000: 36-53; Arruda, Oliveira \& Freitas 2017), Alcácer do Sal (Silva et al. 1980-1981), Setúbal (Soares \& Silva 1986), Lisbon (Arruda 2000: 113-127; Sousa 2016) and Santarém (Arruda 1993, 2000: 137-221; Arruda \& Sousa 2018). Furthermore, other sites - which could be colonial in nature appear to have been founded ex novo, such as Abul A (Alcácer do Sal) (Mayet \& Silva 2000), and possibly Tavira (Maia 2000, 2003) and Quinta do Almaraz (Almada) (Barros, Cardoso \& Sabrosa 1993; Batalha \& Barros 2018).

Meanwhile, and following the collapse and disaggregation of the socio-political formations of the Late Bronze Age, countryside communities seem to have undergone a long-lasting crisis. As far as we can tell from archaeological records, these communities were not reorganised until the late 7 th, and especially the 6th, century BCE. (Arruda 2001; Mataloto, 2004a, b, 2007, 2010-2011; see also contributions in Jiménez Ávila 2017). However, the situation emerging in the inner areas at this time is completely different both from 
that preceding Late Bronze Age and from that developed among the so-called "orientalising" coastal communities. This area socio-political landscape is now characterized by a relatively large number of small, rural, and heterarchical communities that are apparently articulated in differentiated, small-scale, and sub-regional groupings or networks (Beirão 1986; Arruda 2001; Maia \& Maia 1986; Mataloto 2004b, 2007; Jiménez Ávila 2017).

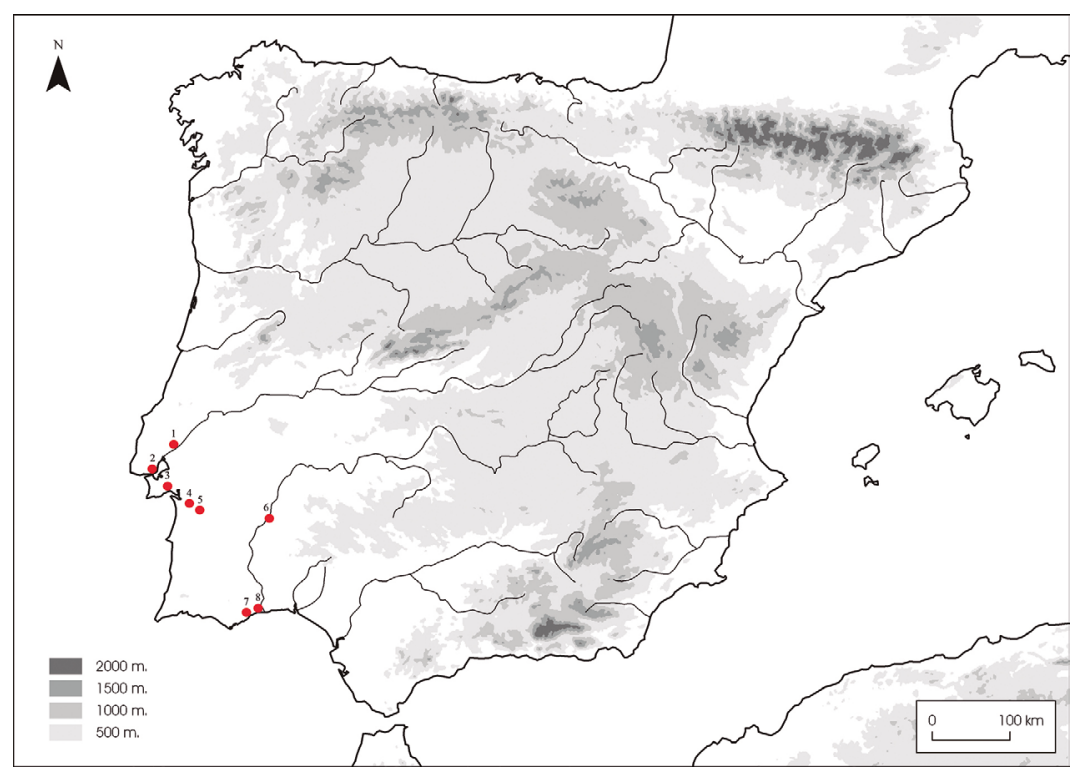

Fig. 1. Location of the main "orientalising" sites mentioned in the text: 1 - Santarém; 2 - Lisbon; 3 - Quinta do Almaraz (Almada); 4 - Abul A (Alcácer do Sal); 5 - Alcácer do Sal; 6 - Castro dos Ratinhos (Moura); 7 - Tavira; 8 - Castro Marim.

Source: Cartographic base: Trabajos de Prehistoria, Consejo Superior de Investigaciones Cientificas (CSIC). ${ }^{2}$

The panorama for the remainder of the Early Iron Age is, first and foremost, one of a striking diversity, which is best illustrated by the recorded variations in the burial practices of these communities (Arruda 2004; Mataloto 2010-2011; Gomes 2014-2015, 2016). Despite the few known "orientalising" necropolises associated with coastal areas - such as Alcácer do Sal (Gomes 2016) or Tavira (Arruda, Covaneiro \& Cavaco 2008), where we find burial traditions and assemblages very similar from other "orientalising" communities in southern Iberia and beyond, - several

2 Available at: $\langle$ https://bit.ly/32HLUvc $\rangle$. Access in: 21 jul. 2020. distinctive burial groups and traditions can be identified in the inner regions of southern Portugal (FIGURE 2).

The necropoleis of the Ourique region, with their characteristic funerary architecture (FIGURE 2), seems to have concomitantly adopted cremation and inhumation (Beirão 1986; Silva \& Gomes 1992; Correia 1993, 2008; Arruda 2001; Soares \& Martins 2013). However, in a certain number of necropoleis, burials were exclusively in cist tombs (FIGURE 2), comprising inhumation only (Costa 1967; 1972; Rocha 1972; Veiga 2005; Deus \& Correia 2005; Barros et al. 2008; Cardoso \& Gradim 2006; 2008a). A third group includes the recently identified necropoleis of the Beja region (FIGURE 2), 
with their rock-cut tombs inhumation graves often surrounded by rock-cut ditches, delimitating burial enclosures (see contributions in Jiménez Ávila 2017). Finally, further north, in Central Alentejo (FIGURE 2), burial documentation is scarce; yet, it suggests once again diverse solutions, combining innovative features, as deposing the cremated remains in urns, with particular ways to conceive and structure burial spaces reminiscent of much older prehistoric models (Mataloto 2010-2011; see also below).

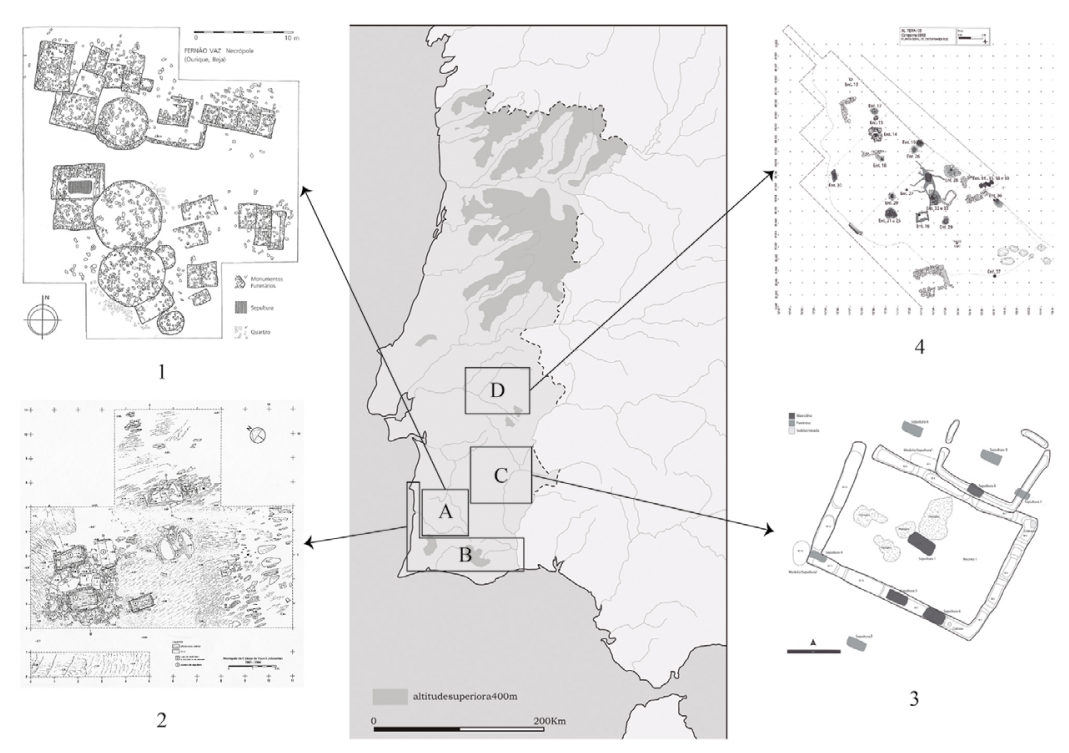

Fig. 2. Main Early Iron Age burial traditions of the inner southern territories of Portugal: A - Tumular necropoleis; B - Cist necropoleis; C - Enclosure necropoleis; D - Necropoleis of Central Alentejo (various scales).

Source: 1 - Correia (2008); 2 - Cardoso \& Gradim (2006); 3 - Pereiro, Mataloto \& Borges (2017); 4 - Mataloto (2010-2011).

This diversity in burial practices and rituals mirrors the socio-cultural fragmentation of the southern territories of Portugal during this period. Such fragmentation can be considered a result of the different ways in which local communities reacted and adapted to the incorporation of the southern Portugal in trade networks of Mediterranean-scale (see Gomes 2016: 482-499). However, to better understand these diverse responses and how they connect with both local and social conditions and political and identity strategies we must develop new tools and models that emphasise the dynamic and contextualised nature of local, cultural, and representational constructs in detriment of a static and normative view of culture (Vives-Ferrándiz Sánchez 2008; Arruda 2009).

\section{Spheres of interaction and scales of integration in the Early Iron Age of southern Portugal: an exploratory approach}

The short overview allows us to infer that the southern communities of Portugal went through a fairly common historical process during the Early Iron Age. Yet, the archaeological record clearly indicates that each of them occupied a different position within that process, which can no longer be deemed as a linear and homogeneous process of acculturation or diffusion of "orientalising" cultural traits (see, for instances, Almagro-Gorbea 1983; Beirão 1986).

Paraphrasing the title of a classical work of Ana Margarida Arruda (1996), we cannot simply look at the regularities in the archaeological record - those common elements 
throughout large portions of the southern Iberian Peninsula; rather, we must pay special attention to its particularities and specificities, its variations, which enables the distribution of local communities along a broad spectrum of cultural solutions.

Thus, we must revaluate the presence of certain elements traditionally considered "fossilguides" of some large-scale cultural horizons as the "orientalising" or "Tartessian" horizons (Beirão 1986; Gamito 1988; more recently, Torres Ortiz 2002, 2005; Almagro-Gorbea \& Torres Ortiz 2009a). To reassess their meaning, we must relinquish the simplistic analysis of the mere presence/absence and geographic distribution criteria to analyse the contexts in which such elements are used, and the social meanings with which they are locally imbued. This denotes the need for further in-depth studies on specific consumption patterns and the ways by which they became embedded in identity and representational practices.

The identities and representational practices of Early Iron Age communities in southern Portugal were profoundly restructured due to the collapse of the socio-political formations in the Late Bronze Age and the rise of local networks that had a completely different geometry and were deeply embedded in larger transregional networks (Arruda 2009; Gomes 2016). This apparently gradual and dynamic restructuration, seems to have been grounded on a socially-negotiated combination between "traditional" local elements, which played a legitimizing and rooting role in a fast changing context (Mataloto 2010-2011; Gomes 2016; Gomes \& Arruda 2019), and exogenous elements, which were actively selected and deployed by local communities (Gomes 2014, 2016, with bibliography). Such combination varied from site to site and from area to area according to each community position in the overall sociopolitical network and also each group's (and its elite) active and conscious choices.

However, even this scheme may present some limitation in its interpretative potential: polarizing "local" and "exogenous" tends to group elements of distinct origins and biographies while masking more complex combinations that express each group's specific representational strategies. In turn, such strategies operate on multiple levels:

1. At a community's internal level, in which these strategies intersected with the internal diversity and social differentiation of each group;

2. At a local and inter-group level, as the political fragmentation identified from the archaeological record suggests that each community required representational mechanisms vis-à-vis their immediate neighbours;

3. At a regional inter-group level, which enables the diffusion of certain representational practices common to a vast portion of the southwestern Iberian Peninsula, which, by times, was (mis) identified as a shared ethnic identity;

4. And finally, at a transregional level, in which individuals and communities more directly embedded in the Phoenician socio-economic network developed representational strategies that were projected onto a wider Mediterranean context.

Although these different integration and interaction scales are naturally complimentary, they acquire different importance depending on each community relative position within the social, political, and economic networks of the region. The different positions they occupy help explain their aforementioned diverse burial record, which materialize the different combination logics in which the group's representation was grounded.

To better understand how this multi-scale approach can be applied into the archaeological record, let us briefly look back to the Early Iron Age necropoleis in the inner-southern territory of Portugal (FIGURE 3). First, these necropoleis architectural features provide us clear evidences of emulation, and in some cases reinvention, of funerary models with deep regional roots (Mataloto 2010-2011; Gomes 2016; Gomes \& Arruda 2019). 


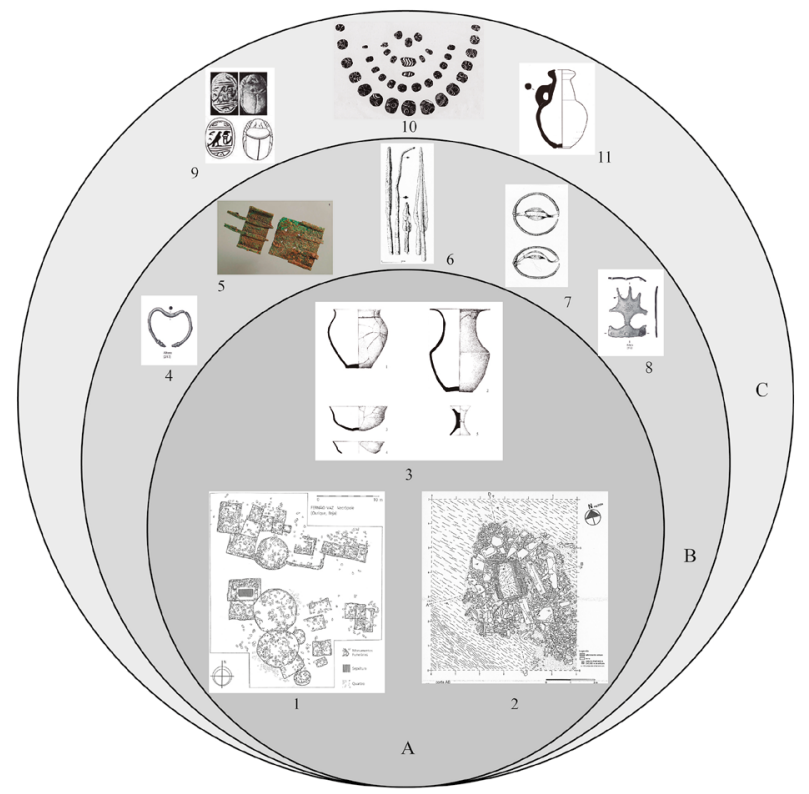

Fig. 3 - Spheres of interaction and scales of integration in the Early Iron Age of inner southern territories of Portugal: A - local/microregional scale B - Macroregional scale C - Transregional scale (various scales).

Source: 1 - Correia (2008); 2 - Cardoso \& Gradim (2008a); 3 - Dias, Beirão \& Correia (1971); 4 -Mataloto (20102011); 5 - Arruda et al. (2017); 6 - Beirão (1986); 7 - Beirão (1986); 8 - Mataloto (2010-2011); 9 - Fonte Santa apud Almagro-Gorbea \& Torres Ortiz (2009); 10 - Silva \& Gomes (1992); 11 - Salvador Mateos \& Pereira (2017).

This is particularly clear regarding the cist necropoleis (Costa 1967, 1972; Rocha 1972; Veiga 2005; Deus \& Correia 2005; Barros et al. 2008; Cardoso \& Gradim 2006, 2008a) and, especially, the tumular architecture of the necropoleis of the Ourique region (Beirão 1986; Correia 1993; Arruda 2001) (FIGURE 2; FIGURE 3). In both cases, the communities who used these necropoleis seem to have faithfully adhered to burial models dating back to the Middle Bronze Age: the cist necropoleis are strongly geographically correlated with areas where cist burials were the most characteristic burial solution (Santos, Soares \& Silva 1975; Silva \& Soares 1979, 1981, 2009; Gomes et al. 1986; Cardoso \& Gradim 2008b; Gomes, M.V. 2015), while tumular necropoleis distribution resembles that of the "Atalaia type" of the same period (Schubart 1975).

We found no clear-cut regional precedent for the enclosure necropoleis of the Beja region (see contributions in Jiménez Ávila, 2017), but they seem to correspond geographically to an area where rock-cut structures - especially hypogea
(Schubart 1975: 257-258; Alves et al. 2010; Rodrigues et al. 2010; Valério et al. 2012; Filipe et al. 2013) - was the predominant Bronze-Age burial tradition, often located near or even in the same area as the later Early Iron Age necropoleis (e.g., Pereiro, Mataloto $\&$ Borges 2017) (FIGURE 3). These enclosure necropoleis have no immediate parallels outside this area, allowing us to consider them as an eminently local development.

Further north, the sui generis necropolis of Tera (Mora) (Mataloto 2010-2011) as a whole represents a prime example of the process of appropriating and reworking ancestral burial models. A complex combination of burial solutions seems to have co-existed in the area, covered by a superstructure made of stone that strongly resemble the numerous prehistoric megalithic tumuli of Central Alentejo, in a process of reinventing and constructing a very specific memory discourse (Mataloto 2010-2011: 92-93).

Another feature of these necropoleis material record that is clearly rooted in local tradition is the pottery repertoire: hand-made wares were 
predominant in most of the aforementioned burial groups (whereas wheel-made wares prevailed in coastal areas), as well as shapes inherited from the Late Bronze Age repertoire (Dias, Beirão \& Coelho 1971; Beirão 1986; Arruda 2001; Deus \& Correia 2005; contributions in Jiménez Ávila 2017; however, see Mataloto 2010-2011) (FIGURE 3). Other shapes were also identified and, despite not having regional precedents, they seem to correspond to local developments (Arruda 2016).

At another level, we must situate certain elements that, due to their vast geographic distribution throughout and beyond the southwestern Iberian Peninsula, were often unduly considered the result of a social, political, and even cultural integration of this entire region into a single and rather homogeneous unit. Among these elements, we could mention weaponry represented mostly by spearheads in the Early Iron Age (FIGURE 3), following relatively widespread typological modeling (Beirão 1986: Arruda 2001; Barros et al. 2008: 49; Soares \& Martins 2013) - and a number of clothing and adornment, such as several bracelets, fibulae, and belt clasps (Gomes 2016, with bibliography; see also contributions in Jiménez Ávila 2017) (FIGURE 3).

These elements have often been used as objects of homogenising interpretations that unduly attributes their distribution to the integration among different areas in a growing political entity (see, for instances, Torres Ortiz 2002, 2005; Almagro-Gorbea 2008; Almagro-Gorbea \& Torres Ortiz 2009a) or, alternatively, in a centre-periphery model orbiting around what is identified as the nuclear area of Tartessos (Beirão 1986; Gamito 1988). However, these element functional nature evinces that they were part of certain social codes - fashion codes, in a sense - associated with the representational schemes adopted by specific social groups.

The use of such elements can be considered not only part of the strategies of these elites to assert their social prominence within their community by shaping power discourses, but also as a representational strategy to be deployed in socio-political relations with other communities at regional scale. In view of the lack of further contextual analyses, these elements should be set in a second sphere, considering a broader geographical scope but a more specific social incidence within the community. However, this sphere is inseparable from the previous one: legitimizing dominant social groups relies on demonstrating their deep local roots in adhering to ancestral practices and adopting representational strategies that ensure their integration in wider regional networks, as community representatives.

Finally, in these same assemblages, we find elements clearly associated with transregional circulation networks (FIGURE 3), as adornment elements - glass, faience, carnelian, and amber beads (Gomes 2014; 2018; Soares, Baptista \& Rodrigues 2016: 132-133; see also contributions in Jiménez Ávila 2017), - amulets (Almagro-Gorbea \& Torres Ortiz 2009b; see also contributions in Jiménez Ávila 2017), and scented substances - first transported in pottery vessels, such as the Phoenician-type "oil bottles" (Gomes, F.B. 2015b, 2019), and later in core-formed glass vessels (Feugère 1989; Fabião 2001).

These elements indicate that these communities had some degree of access to longrange trade networks. However, their presence is intimately related to the earlier discussed sphere of interaction, as they were most certainly deployed in regionally shared representational strategies, although heavily dependent on transregional trade and practices from the Mediterranean world.

The various spheres of interaction and scales of integration discussed in this work (FIGURE 3) should be considered inextricable from each other and perfectly articulated within each community as part of complex identity and representational strategies. These strategies vary from group to group, region to region, due to each community (or group of communities) position within the overall socio-political networks of this period. To fully understand them, we must conduct an in-depth contextual analysis of each case, avoiding generalizations and extrapolations - which in past times severely 
hindered our understanding of the complexity of the Early Iron Age of southern Portugal (for a recent appraisal, see Gomes \& Arruda 2019).

\section{The way forward: some concluding remarks}

In the previous pages, we attempted to depict the diverse and complex development of Early Iron Age communities in southern Portugal, by illustrating how the Phoenician presence triggered complex and wide-ranging processes of social, political, and territorial transformation. Yet more important, the Portuguese case briefly discussed here evinces that the results of such presence were far from homogeneous or unilinear.

The transformational processes unleashed after the collapse of the Late Bronze Age socio-political formations were determined not exclusively by exogenous cultural outputs, but also by local/regional structures and practices especially local agencies and strategies of identity and representation. This explains why oriental and "orientalising" cultural traits and materials are combined with elements deeply rooted in local traditions (whether real or (re)invented) and embedded in local representational practices and identity strategies.

Far from being indicators of acculturation and homogenization, these wide-spread elements, either regional or transregional, were apparently deployed as part of a common language, aimed at asserting each community's identity and status at the various scales of the new overall socio-political networks. However, their importance within local cultural assemblages varied according to the community real or perceived position in the complex balance of those networks and to each group active cultural and identity options.

Further studies must continue to assess the strategies underlying these cultural and identity options, as well as their evolution, reassessing the importance of external factors for local groups socio-political development and finding more compelling models to interpret archaeological record diversity. This is precisely the note with which we should conclude this brief contribution: considering the growing number of research on the Phoenician presence in the far western portions of the Iberian Peninsula and its impact on local communities, as well as the consequent new data that sheds more light on this subject, the available depiction seems to become more and more complex, layered, and fragmented. We suggest further studies to redraw attention to a narrowed analysis to better recognize and understand the diversity, dynamism, and complexity of the Early Iron Age communities of southern Portugal.

GOMES, F. B. Para lá do binómio indígena/fenício: esferas de interação e escalas de integração na I idade do ferro do Sul de Portugal (séculos VIII - V a.C.) . R. Museu Arq. Etn., 33: 15-27, 2019.

Resumo: A chegada dos primeiros comerciantes e colonos Fenícios ao Ocidente da Península Ibérica desestabilizou os delicados equilíbrios das redes regionais do Bronze Final, pondo assim em marcha um amplo processo que haveria de alterar por completo a paisagem sociopolítica do Sul de Portugal. Contudo, o volume crescente de dados demonstra hoje que longe de ter sido um processo simples e linear, a reestruturação que se seguiu foi complexa e dinâmica. Nesta contribuição, argumenta-se que os modelos "tradicionais" baseados numa visão normativa da cultura não permitem já explicar de forma satisfatória a diversidade do registo arqueológico e que, portanto, se impõe desenvolver abordagens novas e mais matizadas. Sugere-se, em particular, que essa diversidade é o reflexo de discursos de representação específicos nos quais elementos "tradicionais" e outros inovadores, frequentemente exógenos, foram 
combinados de acordo com discursos de identidade variáveis, historicamente situados e socialmente negociados destinados a ser projetados em múltiplos níveis, do contexto microrregional das interações intra e intergrupais ao contexto macrorregional do Mediterrâneo.

Palavras-chave: Bronze Final; I Idade do Ferro; práticas funerárias; práticas de representação; discursos identitários.

\section{Bibliographic References}

Almagro-Gorbea, M. (Dir.). 2008. La necrópolis de Medellín III. Real Academia de la Historia, Madrid.

Almagro-Gorbea, M. 1983. Colonizzazione e acculturazione nella penisola iberica. In: ÉCOLE FRANÇAISE DE ROME. Modes de contacts et processes de transformation dans les sociétés anciennes. École Française de Rome, Rome, 429-461.

Almagro-Gorbea, M.; Torres Ortiz, M. 2009b. Los escarabeos fenicios de Portugal: un estado de la cuestión. Estudos Arqueológicos de Oeiras 17: 521-554.

Almagro-Gorbea, M; Torres Ortiz, M. 2009a. La colonización de la costa atlántica de Portugal: ¿Fenicios o Tartesios? In: Actas do X Colóquio sobre Línguas e Culturas Paleohispânicas, 2009, Zaragoza.

Alves, C. et al. 2010. Hipogeos funerarios del bronce pleno en Torre Velha 3. Zephyrus 66: 133-153.

Arruda, A.M. 1993. A ocupação da Idade do Ferro da Alcáçova de Santarém no contexto da expansão Fenícia para a fachada Atlântica peninsular. Estudos Orientais IV: 193-214.

Arruda, A.M. 1996. Particularidades, especificidades e regularidades na Idade do Ferro do Sul de Portugal: aproximação a um modelo explicativo. In: Villar, F.; Encarnação, J. (Eds.). La Hispania Prerromana. Actas del VI Coloquio sobre Lenguas y Culturas Prerromanas de la Península Ibérica. Universidad de Salamanca, Salamanca, 37-50.
Arruda, A.M. 2000. Los Fenicios en Portugal. Fenicios y mundo indígena en el centro ysur de Portugal (siglos VIII-VI a.C.). Universidad Pompeu Fabra, Barcelona.

Arruda, A.M. 2001. A Idade do Ferro pósorientalizante no Baixo Alentejo. Revista Portuguesade Arqueologia 4: 207-291.

Arruda, A.M. 2004. Necrópoles proto-históricas do sul de Portugal: o mundo oriental e orientalizante. In: González Prats, A. (Ed.). El mundo funerario: Actas del III Seminario Internacional sobre Temas Fenícios. Universidad de Alicante, Alicante, 457-494.

Arruda, A.M. 2005. Orientalizante e pósorientalizante no Sudoeste Peninsular: geografias e cronologias. In: Celestino Pérez, S.; Jiménez Ávila, J. (Coords.). El Período Orientalizante. CSIC, Madrid, 277-304.

Arruda, A.M. 2009. Os espaços funerários e a construção de novas entidades sociais e culturais do extremo ocidente europeu (1 $1^{\circ}$ Milénio A.N.E.). Estudos Arqueológicos de Oeiras 17: 513-520.

Arruda, A.M. 2016. À vol d’oiseau: pássaros, passarinhos e passarocos na Idade do Ferro do Sul de Portugal. In: Sousa, A.C.; Carvalho, A.; Viegas, C. (Eds.). Terra e água: escolher sementes, invocar a deusa: estudos em homenagem a Victor S. Gonçalves. Uniarq, Lisboa, 403-424.

Arruda, A.M.; Covaneiro, J.; Cavaco, S. 2008. A necrópole da Idade do Ferro do Convento da Graça, Tavira. Xelb 8: 117-135. 
Arruda, A.M.; Oliveira, C.; Freitas, V.T. 2017. Castro Marim, entre indígenas, Fenícios e Tartéssicos. In: Jiménez Ávila, J. (Ed.). Sidereum Ana III: el Río Guadiana y Tartessos. Consorcio Ciudad de Mérida, Mérida, 443-466.

Arruda, A.M.; Sousa, E. 2018. A I Idade do Ferro na Alcáçova de Santarém: os resultados da campanha de 2001. Onoba 6: 57-95.

Arruda, A.M. et al. 2017. A necrópole da Vinha das Caliças. In: Jiménez Ávila, J. (Ed.). Sidereum Ana III: el Río Guadiana y Tartessos. Consorcio Ciudad de Mérida, Mérida, 187-226.

Barros, L.; Cardoso, J.L.; Sabrosa, A. 1993. Fenícios na Margem Sul do Tejo: economia e integração cultural do povoado do Almaraz, Almada. Estudos Orientais IV: 143-192.

Barros, P. et al. 2008. A cista dos Gregórios (Silves). Xelb 5: 41-52.

Batalha, L.; Barros, L. 2018. Alguns elementos novos sobre Almaraz. Cira-Arqueologia VI: 50-69

Beirão, C.M. 1986. Une civilisation protohistorique du Sud du Portugal (Ier Âge du Fer). Éditions du Boccard, Paris.

Berrocal-Rangel, L.; Silva, A.C. 2010. O Castro dos Ratinhos (Barragem do Alqueva, Moura). Escavações num povoado proto-histórico do Guadiana, 2004-2007. Museu Nacional de Arqueologia, Lisboa.

Cardoso, J.L.; Gradim, A. 2006. A necrópole da Idade do Ferro de Cabeço da Vaca. Xelb 6: 203-226.

Cardoso, J.L.; Gradim, A. 2008a. A necrópole de cistas da Idade do Bronze das Soalheironas: primeira notícia dos trabalhos realizados e dos resultados obtidos. Promontoria 6: 223-248.

Cardoso, J.L.; Gradim, A. 2008b. O núcleo II da necrópole da Idade do Ferro de Cabeço de Vaca. Xelb 8: 103-115.
Correia, V.H. 1993. As necrópoles da Idade do Ferro do Sul de Portugal: arquitectura e rituais. Trabalhos de Antropologia e Etnologia 2: 351-370.

Correia, V.H. 2008. Fernão Vaz: um caso de estudo da paisagem rural do sudoeste no período orientalizante. In: Rodríguez Díaz, A.; Pavón Soldevila, I. (Eds.). Arqueología de la Tierra: paisajes rurales de la protohistoria peninsular. Universidad de Extremadura, Cáceres, 181-194.

Costa, J.M. 1967. O tesouro fenício ou cartaginês do Gaio. Ethnos 5: 529-537.

Costa, J.M. 1972. O tesouro púnico-tartéssico do Gaio. In: Actas das II Jornadas da Associação dos Arqueólogos Portugueses, 1972, Lisboa.

Deus, M.; Correia, J. 2005. Corte Margarida: mais uma necrópole orientalizante no Baixo Alentejo. In: Celestino Pérez, S.; Jiménez Ávila, J. (Coords.). El período orientalizante. CSIC, Madrid, 615-618.

Dias, M.M.A.; Beirão, C.M.; Coelho, L. 1971. Duas necrópoles da Idade do Ferro no Baixo-Alentejo: Ourique. O Arqueólogo Português 3: 175-219.

Dietler, M. 2010. Archaeologies of colonialism: consumption, entanglement, and violence in Ancient Mediterranean France. University of California Press, Berkeley.

Fabião, C. 2001. Importações de origem mediterrânea no interior do sudoeste peninsular nasegunda metade do I Milénio a.C.: materiais da Cabeça de Vaiamonte, Monforte. In: Tavares, A.A. Os púnicos no Extremo Ocidente. Universidade Aberta, Lisboa, 197-228.

Feugère, M. 1989. Les vases en verre sur noyau d'argile en Méditerranée nord-occidentale. In: Feugère, M. (Ed.). Le verre préromain en Europe occidentale. Éditions Monique Mergoil, Montagnac, 29-62. 
Filipe, V. et al. 2013. Bronze Age funerary spaces in Outeiro Alto 2: the hypogea cemetery. Zephyrus LXXI: 107-129.

Gamito, T.J. 1988. Social complexity in Southwest Iberia, 800-300 B.C.: the case of Tartessos. British Archaeological Reports, Oxford.

Gomes, F.B. 2014. Importações mediterrâneas em contextos "Pós-Orientalizantes" do Sul de Portugal (séculos VI-IV a.n.e.). Onoba 2: 27-44.

Gomes, F.B. 2014-2015. O mundo funerário da I Idade do Ferro no Sul do actual território português: notas para uma síntese. Arqueologia \& História 66-67: 47-62.

Gomes, F.B. 2015a. The West writes back: cultural contact and identity discourses in the Late Bronze Age and Early Iron Age of Southern Portugal. In: Babbi, A. et al. (Eds.). The Mediterranean mirror: cultural contacts in the Mediterranean Sea between 1200 and 750 B.C. RGZM, Mainz, 305-317.

Gomes, F.B. 2015b. As “oil bottles” de tipo fenício no território português e o consumo de substâncias aromáticas. O Arqueólogo Português 3: 289-310.

Gomes, F.B. 2016. Contactos culturais e discursos identitários na I Idade do Ferro do Sul de Portugal (sécs. VIII - V a.n.e.): leituras a partir do registo funerário. Tese de Doutorado. Universidade de Lisboa, Lisboa.

Gomes, F.B. 2018. La cornalina en el Bronce Final y la Edad del Hierro del Sur de Portugal. Lucentum XXXVII: 55-74.

Gomes, F.B. 2019. Las oil bottles fenicias en la península ibérica: novedades y perspectivas de la investigación. Pyrenae 50: 85-107.

Gomes, F.B.; Arruda, A.M. 2019. On the edge of history? The Early Iron Age of southern Portugal, between texts and archaeology. World Archaeology 51: 1-17.
Gomes, M.V. 2015. The Vale da Telha Necropolis (Aljezur) in the Context of the Southwest Iberian Bronze Age. Instituto de Arqueologia e Paleociências, Lisbon.

Gomes, M.V. et al. 1986. A necrópole da Vinha do Casão (Vilamoura, Algarve) no contexto da Idade do Bronze do Sudoeste peninsular. Instituto Português do Património Cultural, Lisboa.

Gosden, C. 2004. Archaeology and colonialism: cultural contact from 5000 BC to the Present. Cambridge University Press, Cambridge.

Hodos, T. 2006. Local responses to colonization in the Iron Age Mediterranean. Routledge, London.

Jiménez Ávila, J. (Ed.) 2017. Sidereum Ana III: el Río Guadiana y Tartessos. Consorcio Ciudad de Mérida, Mérida.

Lyons, C.; Papadopoulos, J.K. 2002. The archaeology of colonialism. Getty Publications, Los Angeles.

Maia, M. 2000. Tavira fenícia: o território para Ocidente do Guadiana, nos inícios do I milénio a. C.. In: González Prats, A. (Ed.). Fenicios y Territorio: Actas del II Seminario Internacional sobre Temas Fenícios. Instituto Alicantino Juan Gil-Albert, Alicante, 121-150.

Maia, M. 2003. Fenícios em Tavira. In: Tavira: território e poder. Museu Nacional de Arqueologia, Lisbon, 57-72.

Maia, M.; Maia, M. 1986. Arqueologia da área mineira de Neves Corvo: trabalhos realizados no triénio 1982-84. Somincor, Castro Verde.

Mataloto, R. 2004a. Meio mundo: o início da Idade do Ferro no cume da Serra d'Ossa. Revista Portuguesa de Arqueologia 7: 139-173.

Mataloto, R. 2004b. Um "monte" da Idade do Ferro na Herdade da Sapatoa: ruralidade epovoamento no I milénio a.C. do Alentejo Central. Instituto Português de Arqueologia, Lisboa. 
Mataloto, R. 2007. Viver no Campo: a Herdade da Sapatoa (Redondo) e o povoamento rural centroalentejano em meados do I milénio a.C. Revista Portuguesa de Arqueologia 10: 135-160.

Mataloto, R. 2010-2011. Os senhores da terra: necrópoles e comunidades rurais do território alto alentejano nos séculos VI-V a.C. Arqueologia ఓ História, 60-61: 77-100.

Mataloto, R. 2012. Os senhores e as serras: o final da Idade do Bronze no Alentejo Central. In: Jiménez Ávila, J. (Coord.). Sidereum Ana II: el río Guadiana en el Bronce Final. CSIC, Madrid, 185-213.

Mataloto, R. 2013. Do vale à montanha, da montanha ao monte: a ocupação do final da Idade do Bronze no Alentejo Central. Estudos Arqueológicos de Oeiras 20: 221-272.

Mayet, F.; Silva, C.T. 2000. L'établissement phénicien d'Abul: Portugal. Diffusion du Boccard, Paris.

Pereiro, T.; Mataloto, R.; Borges, N. 2017. Alentejo, a Sul de Beja: a necrópole sidérica da Quinta do Estácio 6. In: Jiménez Ávila, J. (Ed.). Sidereum Ana III: el Río Guadiana y Tartessos. Consorcio Ciudad de Mérida, Mérida, 303-332.

Rocha, A.S. 1972. A necrópole proto-histórica da Fonte Velha, em Bensafrim. In: Rocha, A.S. Memórias e explorações arqueológicas: volume 3: memórias sobre a Antiguidade. Universidade de Coimbra, Coimbra, 127-141.

Rodrigues, Z. et al. 2010. Contextos funerários do sítio de Alto Brinches 3: dados antropológicos preliminares. In: Actas do V Encontro de Arqueologia do Sudoeste. 2010, Almodôvar.

Salvador Mateos, R.; Pereira, J. 2017. A paisagem funerária a Oeste de Beja no Período Orientalizante: as necrópoles de Carlota (São Brissos) e de Cinco Réis 8 (Santiago Maior). In: Jiménez Ávila, J. (Ed.). Sidereum Ana III: el Río Guadiana y Tartessos. Consorcio Ciudad de Mérida, Mérida, 333-352.
Santos, M.F.; Soares, J.; Silva, C.T. 1975. A necrópole da Idade do Bronze da Provença (Sines, Portugal): nota preliminar. In: Actas del XIII Congreso Nacional de Arqueologia. 1975, Zaragoza.

Schubart, H. 1975. Die Kultur der Bronzezeit im Sudwesten der Iberischen Halbinsel. Walter de Gruyter \& Co., Berlin.

Silva, A.C.F.; Gomes, M.V. 1992. Proto-história de Portugal. Universidade Aberta, Lisboa.

Silva, C.T.; Soares, J. 1979. O monumento I da necrópole do "Bronzedo Sudoeste" do Pessegueiro (Sines). Setúbal Arqueológica 5: 121-157.

Silva, C.T.; Soares, J. 1981. Pré-História da Área de Sines. Gabinete da Área de Sines, Sines.

Silva, C.T.; Soares, J. 2009. Práticas funerárias no Bronze Pleno do Litoral Alentejano: o Monumento II do Pessegueiro. Estudos Arqueológicos de Oeiras 17: 389-420.

Silva, C.T. et al. 1980-1981. Escavações arqueológicas no Castelo de Alcácer do Sal (campanha de 1979). Setúbal Arqueológica 6-7: 149-218.

Soares, A.M. 2013. O sistema de povoamento do Bronze Final no Baixo Alentejo: Bacia do Guadiana. Estudos Arqueológicos de Oeiras 20: 273-302.

Soares, A.M.; Arruda, A.M. 2017. A cronologia de radiocarbono para a Idade do Ferro Orientalizante no território português: uma leitura crítica dos dados arqueométricos e arqueológicos. In: Barceló, J.A.; Bogdanovic, I.; Morell, B. (Eds.). IberCrono 2016: cronometrías para la Historia de la Península Ibérica. CEUR, Aachen, 235-259.

Soares, J.; Silva, C.T. 1986. Ocupação pré-romana de Setúbal: escavações arqueológicas na Travessa dos Apóstolos. In: Actas do I Encontro de Arqueologia Urbana, 1986, Lisboa.

Soares, R.M.; Martins, A. 2013. A necrópole da Nora Velha 2 (Ourique): novos dados e interpretações 20 anos após a sua escavação. In: Arnaud, J.M.; 
Martins, A.; Neves, C. (Coords.). Arqueologia em Portugal. 150 Anos. Associação dos Arqueólogos Portugueses, Lisbon, 661-669.

Soares, R.M.; Baptista, L.; Rodrigues, Z. 2016. Os primeiros enterramentos sidéricosconhecidos na margem esquerda do Guadiana em território português. Revista Portuguesa de Arqueologia 19: 129-141.

Sousa, E. 2016. A Idade do Ferro em Lisboa: uma primeira aproximação a um faseamento cronológico e à evolução da cultura material. Cuadernos de Prehistoria y Arqueología de la Universidad Autónoma de Madrid 42: 167-185.

Torres Ortiz, M. 2002. Tartessos. Real Academia de la Historia, Madrid.

Torres Ortiz, M. 2005. ¿Una colonización tartésica en el interfluvio Tajo-Sado durante la Primera Edad del Hierro? Revista Portuguesa de Arqueologia, 8: 193-213.
Valério, P. et al. 2012. Estudo arqueometalúrgico das dádivas funerárias dos hipogeus do Bronze Pleno do Sudoeste da Horta do Folgão. Estudos Arqueológicos de Oeiras 19: 203-208.

van Dommelen, P. 2005. Colonial interactions and hybrid practices: Phoenician and Carthaginian settlement in the ancient Mediterranean. In: Stein, G. (Ed.). The archaeology of colonial encounters: comparative perspectives. School of American Research, Santa Fé, 109-141.

van Dommelen, P. 2011. Postcolonial archaeologies between discourse and practice. World Archaeology, 43: 1-6.

Veiga, S.P.M.E. 2005. Antiguidades monumentaes do Algarve. Universidade do Algarve, Faro.

Vives-Ferrándiz Sánchez, J. 2008. Negociando Encuentros. Situaciones coloniales eintercambios en la costa oriental peninsular (siglos VIII-VI a.C.). Universitat Pompeu Fabra, Barcelona. 